

\section{Louis Malle}

Published in our centenary year

$\approx 2004 \curvearrowleft$

MANCHESTER

UNIVERSITY

PRESS 
FrEnCH FILM DIRECTORS

DIANA HOLMES and ROBERT INGRAM series editors

DUDLEY ANDREW series consultant

Jean-Jacques Beineix PHIL POWRIE

Luc Besson SUSAN HAYWARD

Bertrand Blier SUE HARRIS

Robert Bresson KEITH READER

Leos Carax GARIN DOWD AND FERGUS DALEY

Claude Chabrol GUY AUSTIN

Claire Denis MARTINE BEUGNET

Marguerite Duras RENATE GÜNTHER

Diane Kurys CARRIE TARR

Georges Méliès ELIZABETH EZRA

Jean Renoir MARTIN O'SHAUGHNESSY

Coline Serreau BRIGITTE ROLLET

François Truffaut DIANA HOLMES AND ROBERT INGRAM

Agnès Varda ALISON SMITH 
FRENCH FILM DIRECTORS

\section{Louis Malle}

\section{HUGO FREY}

Manchester University Press

MANCHESTER 


\section{Copyright (C) Hugo Frey 2004}

The right of Hugo Frey to be identified as the author of this work has been asserted by him in accordance with the Copyright, Designs and Patents Act I988.

Published by Manchester University Press Altrincham Street, Manchester Ml 7JA, UK

www.manchesteruniversitypress.co.uk

British Library Cataloguing-in-Publication Data

A catalogue record for this book is available from the British Library

Library of Congress Cataloging-in-Publication Data applied for

ISBN 0719064562 hardback

० 71906457 o paperback

First published 2004

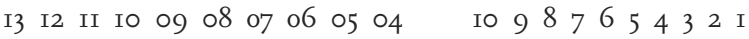

Typeset in Scala with Meta display

by Koinonia, Manchester 